\title{
Chapter 8 \\ Sociomaterial Solar Waste: Afterlives and Lives After of Small Solar
}

\author{
Ankit Kumar (D) and Britta Turner
}

\begin{abstract}
The problem of solar waste from off-grid technologies is attracting increasing attention. This chapter argues that solar waste represents multiple matters of concern; it is a problem of pollution, resource, and social ruin all together. It suggests that while an energy justice framework is well suited to identify issues of distributional, procedural, and recognition justice in relation to solar waste-what we refer to as "afterlives"- - there is a need to engage with postcolonial theories of ethics in order to better grapple with different kinds of social ruins solar waste may represent—what we refer to as 'lives after'.
\end{abstract}

\subsection{Introduction}

Globally, Solar Photovoltaic (PV) deployment has grown at an unprecedented rate since the early 2000s. In the context of the Sustainable Development Goal (SDG) of securing access to electricity for all, off-grid solar has become a dominant technology. Indeed, the latest Off-Grid Solar Market Trends Report published by the World Bank Group's Lighting Global Program shows that the global off-grid industry has seen dynamic growth in the last decade, with an estimated 130 million off-grid solar products sold and 360 million people reached globally since 2010 (GOGLA 2018). In the context of this rapidly expanding market for off-grid solar devices, and along with increasing awareness of the limited life span of small solar-powered devices, the question of what happens to solar devices and their components when they reach the end of life is increasingly timely.

The future challenge of solar PV waste is a global phenomenon. A recent report from the International Renewable Energy Agency (IRENA 2016) estimates that by 2050, global cumulative PV waste volumes could reach 78 million metric tonnes.

\footnotetext{
A. Kumar $(\square)$

Eindhoven University of Technology, Eindhoven, The Netherlands

e-mail: a.kumar@tue.nl

B. Turner

Durham University, Durham, UK
} 
According to the report, this does not only represent a significant challenge in terms of waste management, but also represents significant economic value. The raw materials recovered from PV panels alone could cumulatively yield a value of up to USD 450 million (in 2016 terms) by 2030 (IRENA 2016).

Although a global challenge, solar waste is not the same kind of problem everywhere. As is the case with waste more generally, there are both empirical and conceptual differences between waste in the Global South and waste in the Global North (Millington and Lawhon 2018). Focusing particularly on the Global South and the problem of off-grid solar PV, the Department for International Development (DFID) commissioned a report in 2016 to investigate this issue in this context. The report 'Electronic Waste (E-Waste) Impacts and Mitigation Options in the Off-Grid Renewable Energy Sector' (Magalini et al. 2016) seeks to quantify the extent of solar waste coming from off-grid applications and argues that while the issue of solar waste is still small compared to the scale of the challenge of e-waste more broadly, the current amount of solar waste compares to the amount of e-waste coming from mobile phones. It is also expected to grow significantly.

In both reports, the challenge of solar waste is predominantly framed in terms of establishing the quantity of waste for the purpose of recycling and value extraction. Approaching solar waste in this way makes it a problem of waste management, of encouraging appropriate waste regulations, waste infrastructure and recycling technologies. Yet while the need for waste management is indisputable, the critical question to ask is whether a focus on recycling and waste management alone risks bypassing other opportunities and economies of repair and recycling (Cross and Murray 2018) and whether it hides a number of potential environmental and energy justice issues in the process.

While the question of solar waste is relatively new in the context of off-grid solar technologies and energy access, a rich literature already exists in the broader area of e-waste, which has much to offer in terms of developing a more nuanced understanding of the social life cycles of solar devices as these reach the end-of-life stage. We begin to integrate these insights throughout this chapter. Another aspect that often gets lost in these end-of-life discussions is that of what happens to people's lives, livelihoods, and lifestyles when solar breaks down. By further considering this issue, our analysis adds novelty to the discussion of solar and e-waste.

Why do we want to talk about solar waste at all and specifically with a focus on off-grid solar? Solar in the form of large parks and PV panels is already under discussion and with good reason (IRENA 2016). These large solar installations focus waste in a small area and create hazardous situations. They also make the problem of solar waste visible. In contrast, the waste from off-grid solar is distributed and almost never appears in large quantities; nevertheless, the growing spread of offgrid solar still means that a lot of waste will be generated every year. Yet research in this area is still limited.

The Global Off-Grid Lighting Association (GOGLA) — one of the leading industry associations for off-grid solar-only started tracking sales in 2011, and the distributed nature of off-grid solar devices makes them difficult to account for. Nonetheless, and as outlined above, efforts to estimate future quantities of elec- 
tronic waste in the renewable energy sector in Africa have been made (Magalini et al. 2016). This is an important task and one that touches on a number of potential ethical questions around the distribution of socio-environmental hazards and benefits. Thus, the framing of the problem as a technical or material issue must be complemented by an enquiry into the 'social side' to avoid obscuring important aspects of solar waste (Cross and Murray 2018; see also Sovacool et al. 2018 for a discussion on how technical focus can obscure other societal energy justice issue). At the same time, anticipating and evaluating the volume of future solar waste necessarily involves following material waste flows.

Understanding the social side of solar e-waste and the potential 'ruins left behind' requires a different approach, not following the material waste itself, but the lives of people who come into contact with solar devices as they transition from energy to waste. This raises a different ethical question of responsibility not just for the materials included in solar energy provision, but also for the social lives it touches. Building on this idea, this chapter uses empirical insights from two ethnographic case studies. The first one focuses on the handling of solar waste at a Waste Electrical and Electronic Equipment (WEEE) Centre in Nairobi, Kenya. The second one pays attention to the spaces left behind, the so-called 'social ruins of wasted solar' in Bihar in India.

\subsection{Conceptual Framework: 'Matters of Concern' for Energy Justice at the Stage of Post-being}

What kinds of ethical questions are to be raised in relation to solar waste? What kind of matter of concern is it? What should we be concerned about? And what kinds of concepts and evaluation frameworks are appropriate in order to grapple with these concerns? In order to address these questions, we turn first to Science and Technology studies (STS) and the analysis of matters of concern.

The analysis of 'matters of concern' as opposed to 'matters of fact' is a key approach in the STS literature. Latour (2004: 232) first argued for a move from matters of fact to matters of concern in 2004 stating, 'Matters of fact are only very partial and, I would argue, very polemical, very political renderings of matters of concern and only a subset of what could also be called states of affairs'. By applying the lens of matters of concern to solar waste, we pay attention to the work of framing a problem in a particular way and both the political and material consequences this carries. Mol (2002) has referred to this process of framing or enacting an object in a particular way as ontological politics. It follows that the ontological politics of solar waste determine what kind of a problem - or matter of concern-solar waste is understood to be and therefore what needs to be done about it.

As has already become clear in this introduction, solar waste can be framed as not either an environmental hazard or a potential economic resource, but as both. As is the case with the broader category of e-waste, this makes it thoroughly compli- 
cated to answer the question of what should be done about it (Lepawsky 2018). Thus, in recognising the multiple matters of concern arising from a focus on solar waste, this chapter considers three different renderings of solar waste as a matter of concern. In Sect. 8.3, we focus on solar waste as a matter of pollution and hazard. In Sect. 8.4, we are concerned with solar waste as a resource and as a commodity in the global trade of e-waste. Finally, in Sect. 8.5, we are concerned with social ruins solar waste leaves behind.

Questions of waste and questions of energy are predominantly considered in separate academic literatures. Solar waste, however, brings these together both empirically and conceptually. Solar panels are energy access first and waste after, and we therefore investigate solar waste as part of the energy provision and the energy access agenda. As one particularly profitable avenue allowing such an approach, the growing field of energy justice provides an interdisciplinary, interliterature framework for identifying and considering injustices within the whole system of energy provision, including the stages of production and consumption (Bickerstaff et al. 2013; Jenkins et al. 2016). Here, this connects our thinking of solar waste as a matter of concern to a systems approach.

The three-legged analysis of distributional, procedural, and recognition justice which is central to the energy justice framework (Jenkins et al. 2016) provides a useful tool for identifying 'sites of injustice' relating to different configurations of energy provision. Yet while a concern for post-consumption issues and externalities such as negative impact on future generations is a key part of energy justice concerns (Sovacool et al. 2017), these have so far been less developed. In this regard, end-of-life solar waste challenges the traditional boundaries of an energy justice approach. Because solar waste is what happens when a particular configuration of energy provision falls apart or ends, it sits somewhat precariously within an energy justice framework, which predominantly focuses on systems of production and consumption. In this chapter, postcolonial theory and notions of ethics serve as a complementary lens in order to better approach the question of solar waste and the justice and ethics concerns related to it. Postcolonial theory studies the cultural legacy of colonialism and imperialism. As such, it challenges an energy justice analysis to consider the specific geographical and historical contexts in which solar waste emerges and is handled (Castán Broto et al. 2018). It addresses therefore one of the core shortfalls of the energy justice framework, which is its reliance on western conceptualisations and universalist notions of 'justice' (Sovacool et al. 2017; Castán Broto et al. 2018).

Considering what happens after energy provision, Gupta (2018: 73) has shown how large-scale development projects like dams face widespread resistances in the stages of planning and construction but are forgotten once established: 'in the limelight in the phase of "becoming" but disappear from social scrutiny, discussion, and debate in the phase of "being". In case of energy access projects, the aim of providing access to people is the locus of all attention. Once access is thought as 'achieved', attention shifts to new places that still lack access. Whether access endures or where it is 'achieved', is not a prominent issue (Kumar et al. 2019). There is even less focus on what, following Gupta (2018), we can think of as post-being/after-being, 
the stages of ruins and renewal. This chapter seeks to bring this post-being/afterbeing phase of energy access into scrutiny through our discussions of solar waste given that despite common misconceptions, the material and social 'lives after' solar energy are not external to the whole energy system.

To tackle this, we engage with the idea of 'ruins' rooted in postcolonial literature. Stoler (2013: 11) explains ruins as 'both the claim about the state of a thing and a process affecting it'. As a noun, it focuses on the state of things, and as a verb it points to the projects and process of ruination. The process leading to ruins, ruination, Stoler (2013: 11) suggests, 'is an ambiguous term, being an act of ruining, a condition of being ruined, and a cause of it. Ruination is an act perpetrated, a condition to which one is subject, and a cause of loss. These three senses may overlap in effect, but they are not the same'. Indeed, ruination is a politics that chooses certain places, people, relationships, and things to 'lay waste'. As Howe et al. (2015: 4) remind us, 'historical studies of environmental justice controversies highlight the long-time role in different political power in decisions about waste disposal infrastructure'.

Stoler (2013: 10) notes that the ideas of ruins and ruination offer critical insights for 'grounding processes of actual decomposition, recomposition, and renewed neglect'. Taking a lead from Stoler as we look towards ruins, the fact that there is a 'constant struggle between renewal and ruination' becomes important to confront (Gupta 2018: 73). When we look at solar waste in particular, we observe these processes of renewal through a focus on resource and recycling and ruination through a focus on environmental degradation and lives after. More importantly, we also observe that unequal global and local relationships of power mean that waste embarks on the pathway of renewal for some and ruination for others. In the same way, some benefit from the pathway of renewal of waste as resource while others lose from the pathways of ruination of waste as environmental hazard and wasted lifestyles. This is one fulcrum of the ethical conundrum that waste opens: renewal for some and ruins for others.

In line with Stoler (2013: 9), the consideration of solar waste as a matter of concern opens up the ethical opacity 'between the elusive vectors of accountability and the lasting tangibilities in which ruination operates - and on which such formations thrive'. Through these matters of concerns and our ethnographic focus on specific sites of emergence, disposal, and renewal of waste, we offer a 'situated perspective that acknowledges certain types of insufficiencies as they exist at specific historical moments and geographical locations' (Howe et al. 2015: 6).

\subsection{Solar Waste as Pollution and Hazard ${ }^{1}$}

A prominent matter of concern in relation to solar waste is pollution. Framing solar waste as a problem of pollution, this section brings out questions of toxicity and hazard both to the environment and to human health. It is concerned with the

\footnotetext{
${ }^{1}$ We would like to thank Pirasanth Balasingam for help with the analysis in this section.
} 
questions of what kinds of hazardous materials are contained in solar waste and what kind of future problem they represent.

\subsubsection{What Is in Solar Devices?}

The first point we address is the lack of information about the hazardous materials in solar products, their levels of toxicity, and their impacts on the environment and human health. Solar waste contains a number of hazardous constituents such as toxic, rare, and precious metals. Solar lanterns and solar home systems (SHSs), the two most common solar products available on the market, comprise at least seven basic different components (Fig. 8.1) out of which lithium-ion batteries, solar panels, and electric wires contain the largest amounts of hazardous substances.

Lithium, silicon, and vinyl are the hazardous substances with the largest mass relative to the mass of solar products. Table 8.1 (adapted from Kishore and Monika 2010) shows the hazards of various e-waste components including the printed circuit boards, semi-conductors, and Lithium-ion batteries present in solar lanterns and home systems. When components containing these substances break down in nature, the substances can be absorbed by the soil or seep into groundwater causing localised toxicity. There is already evidence from some countries that when solar products break down, people throw them in latrines or in the fields.

Cadmium, an important component of thin film cells, has been considered carcinogenic in dust and vapour form by National Institute of Occupational Safety and Health (NIOSH), USA (Aman et al. 2015). Its high build-up can lead to 'chlorosis

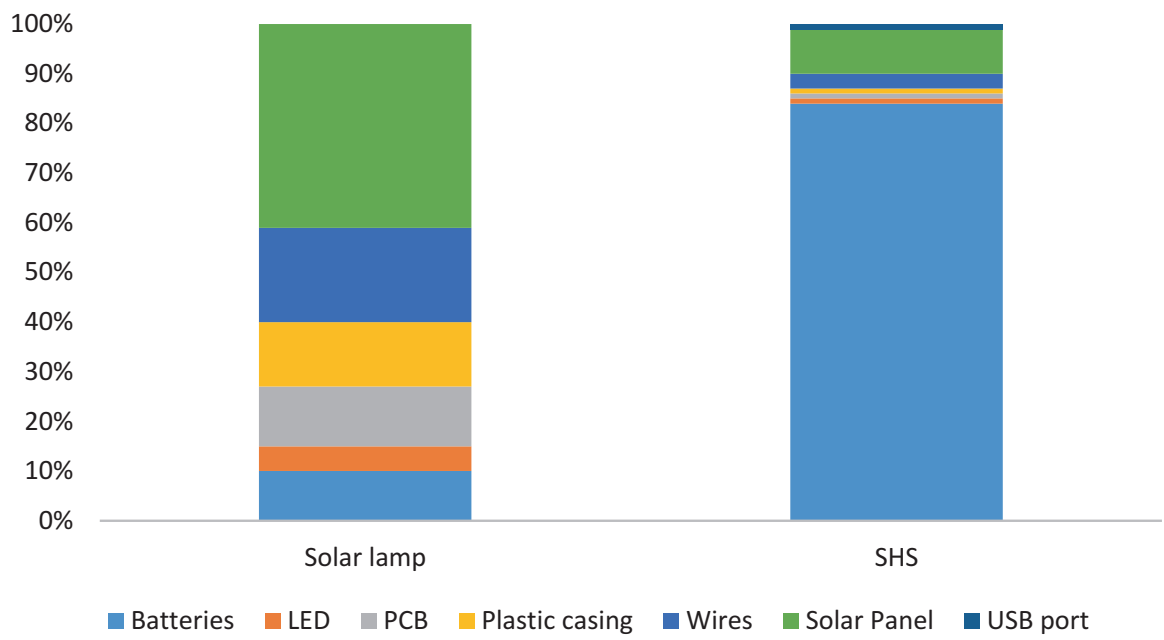

Fig. 8.1 Component composition of solar lamps and solar home system (Data source: Authors' analysis of various solar products available in the off-grid market) 
Table 8.1 e-waste sources similar to components of solar lamps and home systems (source: Kishore and Monika 2010)

\begin{tabular}{|c|c|c|}
\hline E-waste sources & Constituents & Health effects \\
\hline \multirow[t]{2}{*}{$\begin{array}{l}\text { Solder in printed circuit boards, } \\
\text { glass panels, and gaskets in } \\
\text { computer monitors }\end{array}$} & \multirow[t]{2}{*}{ Lead } & $\begin{array}{l}\text { Damage to central and peripheral } \\
\text { nervous systems, blood systems, and } \\
\text { kidney damage }\end{array}$ \\
\hline & & $\begin{array}{l}\text { Adverse effects on brain development of } \\
\text { children; causes damage to the } \\
\text { circulatory system and kidney }\end{array}$ \\
\hline \multirow[t]{3}{*}{$\begin{array}{l}\text { Chip resistors and } \\
\text { semi-conductors }\end{array}$} & \multirow[t]{3}{*}{ Cadmium } & $\begin{array}{l}\text { Toxic irreversible effects on human } \\
\text { health }\end{array}$ \\
\hline & & Accumulates in kidney and liver \\
\hline & & Causes neural damage \\
\hline \multirow{2}{*}{$\begin{array}{l}\text { Relays and switches, and } \\
\text { printed circuit boards }\end{array}$} & \multirow[t]{2}{*}{ Mercury } & Chronic damage to the brain \\
\hline & & $\begin{array}{l}\text { Respiratory and skin disorders due to } \\
\text { bioaccumulation in fishes }\end{array}$ \\
\hline $\begin{array}{l}\text { Galvanised steel plates and } \\
\text { decorator or hardener for steel } \\
\text { housing }\end{array}$ & Chromium & Causes bronchitis \\
\hline Cabling and computer housing & Plastics and PVC & $\begin{array}{l}\text { Burning produces dioxin that causes } \\
\text { reproductive and developmental } \\
\text { problems }\end{array}$ \\
\hline $\begin{array}{l}\text { Electronic equipment and } \\
\text { circuit boards }\end{array}$ & $\begin{array}{l}\text { Brominated } \\
\text { flame-retardants }\end{array}$ & Disrupt endocrine system functions \\
\hline Front panels of CRTs & $\begin{array}{l}\text { Barium, } \\
\text { phosphorus, and } \\
\text { heavy metals }\end{array}$ & $\begin{array}{l}\text { Cause muscle weakness and damage to } \\
\text { heart, liver, and spleen }\end{array}$ \\
\hline $\begin{array}{l}\text { Copper wires, printed circuit } \\
\text { board tracks }\end{array}$ & Copper & $\begin{array}{l}\text { Stomach cramps, nausea, liver damage, } \\
\text { or Wilson's disease }\end{array}$ \\
\hline $\begin{array}{l}\text { Nickel-cadmium rechargeable } \\
\text { batteries }\end{array}$ & Nickel & $\begin{array}{l}\text { Allergy of the skin to nickel results in } \\
\text { dermatitis while allergy of the lung to } \\
\text { nickel results in asthma }\end{array}$ \\
\hline \multirow[t]{2}{*}{ Lithium-ion battery } & \multirow[t]{2}{*}{ Lithium } & $\begin{array}{l}\text { Lithium can pass into breast milk and } \\
\text { may harm a nursing baby }\end{array}$ \\
\hline & & $\begin{array}{l}\text { Inhalation of the substance may cause } \\
\text { lung oedema }\end{array}$ \\
\hline
\end{tabular}

in plants, and necrosis, toxicity, or death in animals' (Malandrino et al. 2017: 7). For humans, severe intoxication can cause 'pulmonary emphysema, kidney dysfunction, and damage to the skeletal apparatus', and long-lasting exposure can lead to 'damage to the peripheral paresis, and central nervous system, as well as to the cardiovascular system, the endocrine system, kidneys' (Malandrino et al. 2017: 7). On the other hand, excessive lead exposure from waste batteries can result in a reduction of immunity. Moreover, due to its biodegradable characteristic, lead persists in the human food chain (Qi and Zhang 2017). Lithium from batteries can also seep into soil and groundwater and be detrimental to human health and the 
environment (Jha et al. 2013). Lithium-ion is one of the biggest components of the solar waste stream and will increase further as Li-ion batteries become more common.

\subsubsection{How Much of This Can We Expect in South Asia?}

Solar products from two prominent solar lamp manufacturers, Panasonic and Azuri, have an average life span of 2 years. ${ }^{2}$ As GOGLA (2018) points out, many products last longer than this period. At the same time, research reveals that many products break down before 2 years (Kumar 2015; Turner 2016). This may result from technical failures or socio-environmental circumstances including user behaviour and the lack of repair infrastructures.

The sales data shown in Fig. 8.2 are averages of the global sales data from 2016, 2017, and 2018 reports from Global Off-Grid Lighting Association (GOGLA 2018) and Lighting Global (Dalberg Advisors and Lighting Global 2018). According to Lighting Global, 30\% of global sales in 2018 were in South Asia (Dalberg Advisors and Lighting Global 2018). We have used this $30 \%$ figure to determine the sales figures for South Asia. From 2011 to 2017, actual sales data show linear increases, but the rate of growth is surprising. Sales totalled $\$ 4$ million in 2017 com-

8000000

7000000

6000000

5000000

4000000

3000000

2000000

1000000

0

201120122013201420152016201720182019202020212022

Solar lamp sales $\quad$ Solar home system sales

Fig. 8.2 Historical and predicted annual sales of small solar in South Asia. The sales figures up to 2017 are actual figures from GOGLA, and the figures from 2018 to 2022 are projections from Lighting Global (Dalberg Advisors and Lighting Global 2018; GOLGA 2018)

\footnotetext{
${ }^{2}$ For its impact analysis, GOGLA assumes an average lifetime of 1.5 times the warranty period. Most solar lamps carry a 1-year warranty.
} 
pare to approximately $\$ 500,000$ in 2011 . This attests to the massive spread of solar in this period. The period from 2018 to 2022 represents the projected sales of solar products (Dalberg Advisors and Lighting Global 2018). During 2017-18, an acceleration in national grid electrification in South Asia led to the downward curve in Fig. 8.2. However, global discourses of sustainability will become more critical in the long term and more people will transition to sustainable energy, securing long-term e-waste challenges (Byrne and Mbeva 2017). Companies might replace decentralised solar with centralised solar energy creating another type of wastes instead of small solar waste, for example (UN ESCAP 2014). The sales figures also show a dominance of solar lamps. However, SHSs are becoming more popular and are expected to overtake solar lamp sales. Taken together, the sales figures and an average life span of 2 years gives us a sense of the extent of the waste of different kinds that we can expect in the coming years.

Framing solar waste as a matter of pollution and hazard highlights in particular two areas where further research is needed. Firstly, there is a need to access the continued sustainability of solar technology, taking into account its material afterlife. A focus on the toxic contents of solar panels and their balance of system encourages questions of how potential socio-environmental consequences at endof-life impact the overall sustainability credentials of the technology. Secondly, there is a concern about where the toxicity becomes a hazard and for whom. There is a need for further studies of emerging solar waste economies to better understand who is at risk.

\subsection{Solar Waste as Resource and Commodity}

Having looked at solar waste as an environmental and health hazard and having achieved a sense of the quantity of waste we could expect in the coming years, we now turn to the second matter of concern in relation to solar waste, namely, its potential role as a resource and as a commodity in the global trade with e-waste. In terms of its constituent parts, solar waste contains many of the same materials as other kinds of electronic waste. This places end-of-life solar devices within existing global e-waste infrastructures and frameworks of governance. Yet although a large part of the challenge of e-waste management has to do with avoiding negative impacts of the global movement of hazardous wastes, as regulated by the Basel Convention, e-waste is not just about hazard, but also about economic value.

Where the framing of solar waste as a source of hazardous pollution above invited questions around the quantity and health impact of future solar waste with related ethics concerns about what kind of damage solar waste may cause for whom, a framing that focuses on the potential value to be extracted from solar waste is different. Considering the future role of solar waste in global e-waste markets invites different questions and different ethical concerns about the distribution of costs and benefits in the handling of solar waste, for example. Many of the materials from solar products can be recovered. As an illustration, the recovery percentages reported 
for glass and aluminium are $97 \%$ and $100 \%$, respectively; for copper and tellurium, the figures are about $80 \%$; and for significantly valued rare metals like indium and gallium, they are $75 \%$ and $99 \%$, respectively (although the rare metals are only about $1 \%$ by weight of the solar panels) (Malandrino et al. 2017).

Looking at end-of-life solar products as a potential source of revenue invites engagement with a body of literature that in recent years has been investigating the geography of the global trade in e-waste and waste more generally. Here, waste is less about pollution and more about the process and politics through which objects and materials are turned into something else, generating markets and employment in the process (Alexander and Reno 2012; Gregson and Crang 2015; Lepawsky 2018). Two things, in particular, are important to take from this literature. Firstly, e-waste is an important secondary resource for developing countries and an area of significant economic activity and politics (Gregson and Crang 2015), which is complex and very difficult to trace. The geography of the global trade in electronic discards no longer reflects the assumption, which to a large extent underpins international regulations (the Basel Convention), that rich countries in the West are dumping waste on poor countries in the South. Instead, e-waste appears highly regionalised with intra-regional trade accounting for the majority of total trade flows (Lepawsky and McNabb 2010; Lepawsky 2015). Such localisation and regionalisation will be even more evident in off-grid solar waste as the bulk of offgrid solar is sold, used, and discarded in the global South. In this regard, the literature shows that waste and the transformation of it is an economically productive enterprise and a dynamic social and cultural category.

Secondly, the notion of 'waste' is problematic. Current definitions of e-waste frequently do not distinguish between working, repairable equipment (the majority) and materials for recycling. The question of whether an electronic device is waste or non-waste (which can be reused or repaired), hazardous or non-hazardous, is controversial both because it determines which technical pathway the device will take and because it determines which marketplaces it is allowed to enter (Lepawsky 2018). Focusing then on what is being traded rather than how much it weighs shows that the majority of traded e-waste is not actually waste, but repairable electronic devices which are reused, repaired, and sold in second-hand markets (Lepawsky 2018). In the case of solar waste, much of this is already happening within existing repair infrastructures (Cross and Murray 2018).

So, where do off-grid solar systems go when they are no longer in use? According to the literature on consumer waste, they might well stay where they are, at least to begin with. A great deal of domestic electronic and other devices which are no longer in use do not 'go' anywhere, but remain in people's houses stowed away in drawers or on top of cupboards for considerable time before they enter the complex systems of second-hand markets moving up and down different waste hierarchies, for instance (Gregson et al. 2009, 2010, 2013). The extent to which solar-powered devices enter formal and informal repair economies and how well they fare there is insufficiently understood (Cross and Murray 2018). A recent survey of seven countries in Sub-Saharan Africa showed evidence of used batteries from LED lamps being dumped in latrines or in agricultural fields (Bensch et al. 2017), and a large 
proportion of electronic waste is assumed to be discarded along with general waste. What is clear, in other words, is even with better sales data from solar distributors, estimates of future volumes of solar waste and assumptions about if and when they may make their way into recycling commodity pathways are difficult to make.

Qualitative data collected at a visit to the Waste Electrical and Electronic Equipment (WEEE) Centre in Nairobi in December 2018 illustrate how some of the complexities of how e-waste is framed and valued impact on the businesses and people for whom solar waste and other e-waste represent a livelihood. The WEEE Centre receives e-waste from all over Africa, yet the difficulty with off-grid solar waste is its decentralised nature. End-of-life devices, as they are currently handled, do not represent enough financial value for the WEEE Centre to be able to finance their collection or to provide any financial incentive for people to bring them to the centre. The solar waste that does arrive at the centre (which in quantity is roughly a lorry full every week) arrives from Kenya and neighbouring countries due to an arrangement the WEEE Centre has with some of the major solar distribution companies in Africa. These companies rely on the WEEE Centre for disposal of old technologies that have been made redundant by technological advancements or have been collected by the distributor due to technical failure. Regulation and reinforcement of producer responsibility in this area is still weak, however, and a great number of distribution companies operating in Kenya and more widely in Africa do not organise such collections.

The solar waste that does arrive at the WEEE Centre is sent there for disposal rather than refurbishment and is handled much in the same way as old computers, mobile phones, and other types of e-waste. Yet devices that are deemed functioning or repairable (e.g. second-hand computers which have been shipped from western countries) are repaired and refurbished. The WEEE Centre operates a 'Computers for Schools' programme through which these are then sent out to schools across Kenya, for instance. Devices and other e-waste, which are deemed beyond repair, are weighed and documented before being split apart into plastics, iron/steel, and glass, which are all recycled locally and regionally. Components classed as hazardous wastes, including circuit boards, batteries, and other parts containing (valuable) rare earth metals, are sent on to the EU (primarily to Belgium and the Netherlands) for further processing in accordance with international regulations as the WEEE Centre does not currently have the required capacity to be allowed to process it themselves. Although the staff at the WEEE Centre appreciate that international regulation such as the Basel Convention is necessary to govern the global movement of hazardous waste, they note that the framing of e-waste as a matter of pollution and hazard as opposed to a matter of resource and value has consequences for their ability to create a viable business model out of resource recovery.

Scale is an important factor when it comes to resource recovery from waste. The assumption at the WEEE Centre is that the quantities of solar waste in Kenya and neighbouring countries are considerably larger than the relatively small amount they are currently receiving and is set to grow over the next few years. Thus, the difficulty for them is not the processing of the waste but acquiring it in the first place. The WEEE Centre is only able to recover solar waste through particular chan- 
nels, namely, the solar companies. They are well aware, however, that this does not mean that the waste is not recycled. Informal recycling of e-waste in Sub-Saharan Africa is infamous, but also much more complex than the often sensationalist representation of it in global media. The relationship between formal and informal recyclers is ambiguous; the informal sector presents on the one hand a significant challenge for the formal sector by competing for the same resource, but on the other hand, it provides a living for families living on the margins of society: 'People burn wires to get the copper and they pour the acid from the batteries on the ground to get to the lead. And that is very bad both for them and the environment. But you can't just stop that, it provides an income for many families, so we have to think carefully about this' say staff at the WEEE Centre.

Framing solar waste as a resource and commodity in relation to the global e-waste trade then brings out different sets of concerns, ethics, and potential injustices when opposed to framing it as source of pollution. It also shows how a framing that focuses predominantly on avoiding environmental hazard may have unintended consequences for particular stakeholders. When considering future trades in solar waste, questions of the global distribution of equity and procedural justice become much more prominent. Future research in this area needs to better understand who all the different stakeholders are and how different priorities may have unintended consequences.

\subsection{Solar Waste as Lives After}

Understanding how end-of-life solar devices may or may not enter different reuse, repair, and recycling economies also requires better insight into what happens in everyday life when solar energy becomes solar waste. The previous section traced the material solar waste as it travelled away from households to places like the WEEE Centre in Nairobi and highlighted a number of ethical questions concerning the related global trade in e-waste. This case study now questions which ethical questions emerge in the spaces left behind beyond the lifetime of solar devices. Challenging the boundaries of energy justice concerns it focuses on the lives after solar waste, what a postcolonial ethics approach outlined above would conceptualise as its social ruins, the ruins that are people and their lives, lifestyles, and livelihoods.

During ethnographic fieldwork in India in 2011-2012, ${ }^{3}$ the question of what happens to people's lives when devices such as solar lanterns break down became central to Ankit Kumar's research. Generally speaking, the lives after solar lanterns and micro-grids embarked on one of the two pathways when these systems broke down: those who could afford them went on to buy solar home systems; those who could not struggled to cope with kerosene lamps.

${ }^{3}$ For more details, see Kumar (2015). 
Ankit had just finished interviewing some women in a higher caste farmer household in Bijuriya village. There he met Mr. Ramesh Singh who, although he did not like it, went to charge his mobile phone from the solar plate ${ }^{4}$ at a friend's house every day. The village in question did not have electricity from the national grid.

A micro-grid ${ }^{5}$ in Bijuriya, which ran for about a year in 2010-2011, led to an increase in the number of mobile phones. People had a stable source of electricity to charge their mobile phones, which otherwise cost INR 5-10 to charge every time (Kumar 2018). However, the micro-grid's breakdown means that now, people have ended up with a significantly higher economic burden of charging phones than they initially anticipated. How do they cope with these leftover cell phones and the now normalised practice of their frequent use?

There are other social ruins too. A few days later, when Ankit visited Mr. Ramesh Singh's home and interviewed his family, they explained that the micro-grid had made them realise the importance of electric lights and that they had got 'used to' studying and working under them. Entrepreneurs renting solar lamps in villages played on such dependencies, using tactics like giving people solar lamps free for the first week or so, to 'reel them in'. Once people got used to 'better' lights, they stayed on and paid for the lamps.

After becoming 'used to' better lights due to the micro-grid and solar lamps, people find it difficult to work under kerosene lights. Morris (2011: 316) notes that due to their high dependence on vision, humans have a hard time in conditions of low light. Connected to this, like most other people in Bijuriya, Mr. Singh's son explained that the disadvantage of vision under lower illumination is accentuated further when one becomes 'used to' electric lights and then has to go back to kerosene lanterns. He compares it to the struggles of poverty after getting used to a life of wealth. ${ }^{6}$ In short, problems associated with lack of electricity-'better' lights and mobile charging - are exacerbated when people are forced to readapt to a lack of electricity. How do people cope with the absence of these better lights that now they have become so used to?

We raise this question in the light of our earlier discussion on the ethics of ruins and renewal. Waste as material resource has an afterlife of renewal. Waste as material hazard has an afterlife of ruin, ruining nature and human health. What happens to this particular form of ruin: to the lives after solar? What happens to the new mobile phones, their users, and the now socially embedded practice of using mobile phones? What happens to people who now find it difficult to see in the light of old kerosene lamps? Are these social ruins also going through a process of renewal? If they are, what new material and social costs are involved? In short, how do people manage their lives after solar? The current energy justice paradigm does not answer these questions, yet here we show that these questions are central to lives of solar devices and lives of people who engage with these devices.

\footnotetext{
${ }^{4}$ Local name for solar home system.

${ }^{5}$ This was a biomass-based micro-grid, but the everyday experiences of energy users are same regardless of the source of energy generation.

${ }^{6}$ This logic works very well for energy access project that promises to eradicate energy poverty.
} 


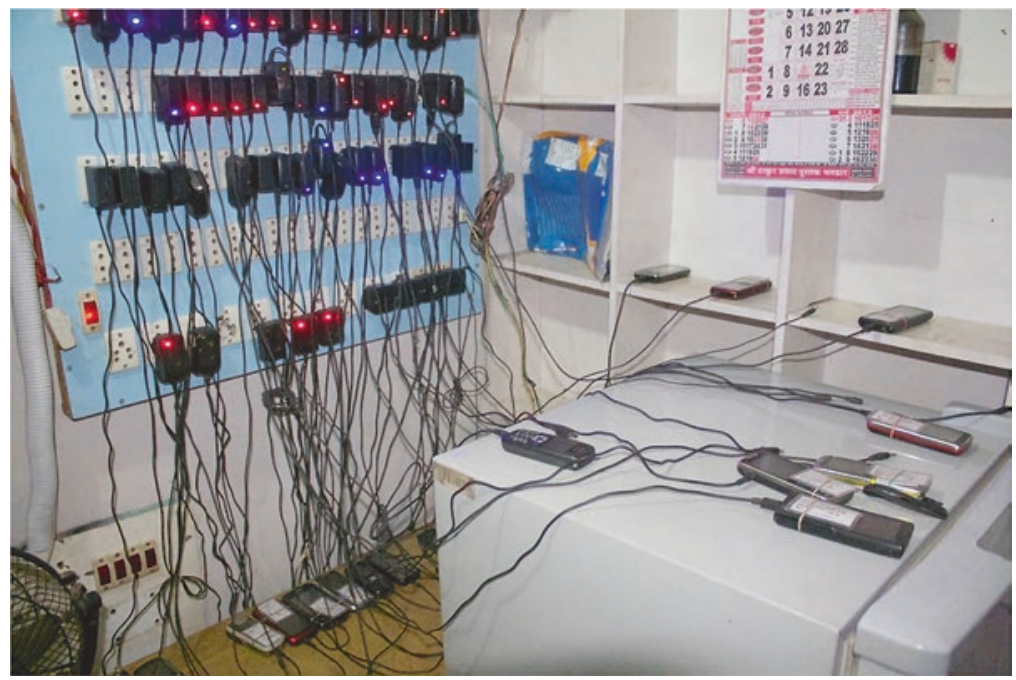

Fig. 8.3 Mr. Gupta's mobile phone charging shop in Hardiya village. People get their phones charged for INR 5-10. Many people own smart phones and use them to watch films and listen to music, which runs the batteries out faster. Because of this, many people have to get their phones changed more than once a day. This creates a substantial economic burden

\subsubsection{Living with Ruins}

People who now own new mobile phones in Bijuriya either: (1) renew their old practice of visiting shops like Mr. Gupta's (as shown in Fig. 8.3) to charge their phones at a high price or, (2) like Mr. Singh, tap into their social network. Where solar networks end, the social networks that existed before solar take over. One can question why this matter at all as even before the micro-grid arrived in the village people had to rely on the commercial mobile charging shops or their own social networks to charge phone. Indeed, this burden existed even before the micro-grid. However, now the burden is bigger. The micro-grid catalysed the purchase of mobile phone, and now most homes own multiple phones. There are more phones to be charged, more money needs to be spent at charging shops, wider social network needs to be tapped into, and more frequent embarrassment needs to be faced with.

Depending on social networks also means that people need to find others within their own social groups to charge their phones. Those who cannot must pay for the expensive charging facilities. In addition, due to their limited mobility in this cultural setting, women often have to depend on male members of the household to charge their phones. With the micro-grid, they could charge their phones by themselves inside their homes. ${ }^{7}$

\footnotetext{
${ }^{7}$ This is certainly true in case of Mr. Singh. He had actually come to charge his wife's mobile phone when Ankit met him.
} 


\subsubsection{Ruins to Renewal}

For others, lives after solar consist of more solar. Mr. Rajendra, another farmer in Bijuriya informed Ankit that when faced with the new problems of coping with an absence of better lights that villagers had become used to and a lack of cost-effective solutions for charging mobile phones, people began looking for alternatives. He explained that before electric lights arrived in the village, they were used to (abhiyast) kerosene lights but that going back to kerosene was now impossible. For this reason, he bought new solar plate and installed lights around his home. He also runs a small TV and fan from this solar plate.

Mr. Rajendra made an important argument. 'Getting used' to electric lights has forced the people in Bijuriya to look for other solutions. Most people in Bijuriya reported that solar plate numbers increased substantially since the arrival and the subsequent shutdown of the micro-grid. This is partly driven by the need for a costeffective solution to charging mobile phones. Thus, solar plays a central role in the lives after. It is easily available and can be readily used. However, this does not solve the problem of material waste; rather, it exacerbates it. Further, not going back was not possible for everyone. Some, including Mr. Singh, could not afford to buy a solar plate. His son had to go back to studying under kerosene lamps, however difficult that might be. Mr. Singh had to go back to frequenting his friend's house to charge mobile phones, however embarrassing that might be.

The two pathways that lives after solar open up bring us back to the earlier two sections on waste. In one pathway, the material (left over mobile phones) and social (being used to better lights) lives and lifestyles solar created threatened to go waste or become hazardous to people by creating new economic burdens. In the second pathway, people take a step forward and buy new solar plates. These lives after then become resources for selling new solar, meaning that solar companies inevitably benefit. As discussed in Sect. 4, resources are for some and hazard for others.

Approaching solar waste through a postcolonial lens enables this line of questioning which does not 'follow the waste' as such but considers the effect the process of bringing electricity to people by means of solar entails and the often unintended consequences this has on the ground (Turner 2019). It questions the wider effect of the empire (Stoler 2008) and the frequent disconnect between the promise of infrastructure, to bring modernity, development, progress, and a better life, and what is actually delivered (Anand et al. 2018). A consideration of lives after as opposed to afterlives in other words forces an ethical position which prevents the socio-cultural effects such 'broken promises' have from being seen as externalities.

\subsection{Conclusions and Comparative Reflections}

Solar waste is a growing problem, but it is not the same kind of problem everywhere and for everyone. As efforts to estimate the future quantity of solar waste are underway, this chapter has considered how multiple framings of solar waste may lead to 
complementary questions about who and what solar waste will come to impact in the future as its volumes grow. Until recently, the question of energy access was disconnected from the issue of waste. The literature on off-grid solar has only recently begun to touch on the question of solar waste, and this chapter furthers this cause. It follows that there is a need for further research to understand the relationship between the socio-material transitions of securing energy access and the types of waste and afterlife they encompass.

Connecting questions around energy and waste challenges the boundaries of energy justice with its dominant focus on systems of production and consumption, by emphasising that consumption is not the end of the story. Ethical notions of ruins and waste derived from postcolonial studies provide useful conceptual tools for this challenge. In this way, attention to the situated and historical context in which solar waste emerges forces questions of not just how it is (to be) handled, but also what legacy it represents to different people.

This chapter has illustrated how the framing of solar waste has consequences for what socio-material challenges it poses-what sites of injustice we should be concerned about. An emphasis on solar waste as pollution and hazardous material focuses the need for waste management. The dominant concerns here relate to a need to protect people and environments from harm. This chapter has illustrated how this framing, which is dominant in international regulations such as the Basel Convention, has unintended consequences for stakeholders such as the WEEE Centre and both the formal and informal waste economies who handle the waste and make a living from doing that.

A critical challenge for the global regulation of solar waste then is to balance multiple framings, solar waste as hazard and solar waste as resource. As we have seen, an emphasis on solar waste as a resource and a commodity in global value chains involves different stakeholders and raises different concerns about the equitable distribution of risks and benefits across value chains. Understanding how synergies and trade-offs exist between these framings requires further research. Both these concerns are around the afterlives of solar energy provision and the material waste this produces and involve 'following the waste' as something which is physically present, material, and tangible. Enrolling a postcolonial perspective, this chapter also pursued a different approach which did not follow the waste but rather recognised the ruins it had left behind.

An emphasis on solar waste as social ruin however is less tangible and relates to an absence of technology or energy materials in spaces where they once were. The concern here is about lives after, about the social, cultural, and political legacy left behind at the end of the technology lifecycle, when solar energy has become solar waste. A postcolonial lens calls for more situated, historical, and ethical enquiries of how the entire process that produces solar waste impacts many different communities and societies in countries of the Global South. Vinay Gidwani (1992) suggests that we see waste both as a noun and as a verb. 'As a noun it serves as dumping ground for all those entities that modern society views as marginal, residual, unimportant, or unpalatable. As a verb it describes the varieties of human behaviour that are unacceptable to modern society. In either grammatical form, the word 'waste' 
hovers in the English language waiting to pounce on subjects and objects at the fringes of society' (Gidwani 1992: 39). In energy justice terms, looking at lives after instead of afterlives unravels different sites of injustice.

This is the purchase of combining an energy justice perspective with postcolonial analysis: it enables a critical and ethical analysis not only of the lives and afterlives of material energy systems such as off-grid solar PV, but also of the lives after, the people and places affected not merely by the solar technologies but the processes through which they enter and exit their lives, and the promises they make in the places where they are deployed.

\section{References}

Alexander, C., \& Reno, J. (2012). Economies of recycling: The global transformation of materials, values and social relations. London: Zed Books.

Aman, M. M., Solangi, K. H., Hossain, M. S., Badarudin, A., Jasmon, G. B., Mokhlis, H., Bakar, A. H. A., \& Kazi, S. N. (2015). A review of Safety, Health and Environmental (SHE) issues of solar energy system. Renewable and Sustainable Energy Reviews, 41, 1190-1204. https://doi. org/10.1016/j.rser.2014.08.086.

Anand, N., Gupta, A., \& Appel, H. (Eds.). (2018). The promise of infrastructure. Durham: Duke University Press.

Bensch, G., Peters, J., \& Sievert, M. (2017). The lighting transition in rural Africa-From kerosene to battery-powered LED and the emerging disposal problem. Energy for Sustainable Development, 39, 13-20. https://doi.org/10.1016/j.esd.2017.03.004.

Bickerstaff, K., Walker, G., \& Bulkeley, H. (2013). Introduction: making sense of energy justice. In K. Bickerstaff, G. Walker, \& H. Bulkeley (Eds.), Energy justice in a changing climate: Social equity implications of the energy and low-carbon relationship (pp. 1-13). London: Zed Books.

Byrne, R., \& Mbeva, K. (2017). The political economy of state-led transformations in pro-poor low carbon energy: A case study of solar PV in Kenya. Brighton. Retrieved from https://opendocs.ids.ac.uk/opendocs/bitstream/handle/123456789/12968/EnergytransKenya.pdf?sequence $=1 \&$ isAllowed $=\mathrm{y}$

Castán Broto, V., Baptista, I., Kirshner, J., Smith, S., \& Alves, S. N. (2018). Energy justice and sustainability transitions in Mozambique. Applied Energy, 228, 645-655. https://doi.org/10.1016/j. apenergy.2018.06.057.

Cross, J., \& Murray, D. (2018). The afterlives of solar power: Waste and repair o ff the grid in Kenya. Energy Research \& Social Science, 44, 100-109. https://doi.org/10.1016/j.erss.2018.04.034.

Dalberg Advisors, and Lighting Global. (2018). Lighting Global: Off-Grid Solar Market Trends Report 2018. Washington, D.C. https://doi.org/10.1017/CBO9781107415324.004.

Gidwani, V. (1992). "Waste" and the permanent settlement in Bengal. Economic and Political Weekly, 27(4), 39-46.

GOGLA. (2018). Global Off-Grid Solar Market Report Semi-Annual Sales and Impact Data. https://doi.org/10.1023/A:1004871704173.

Gregson, N., \& Crang, M. (2015). From waste to resource: The trade in wastes and global recycling economies. Annual Review of Environment and Resources, 40(1), 151-176.

Gregson, N., Metcalfe, A., \& Crewe, L. (2009). Practices of object maintenance and repair: How consumers attend to consumer objects within the home. Journal of Consumer Culture, 9(2), 248-272. https://doi.org/10.1177/1469540509104376.

Gregson, N., Crang, M., Ahamed, F., Akhter, N., \& Ferdous, R. (2010). Following things of rubbish value: End-of-life ships, 'chock-chocky' furniture and the Bangladeshi middle class consumer. Geoforum, 41(6), 846-854. 
Gregson, N., Crang, M., Laws, J., Fleetwood, T., \& Holmes, H. (2013). Moving up the waste hierarchy: Car boot sales, reuse, exchange and the challenges of consumer culture to waste prevention. Resources, Conservation and Recycling, 77, 97-107.

Gupta, A. (2018). The future in ruins: Thoughts on the temporality of infrastructure. In N. Anand, A. Gupta, \& H. Appel (Eds.), The promise of infrastructure (pp. 62-79). Durham: Duke University Press.

Howe, C., Lockrem, J., Appel, H., Hackett, E., Boyer, D., Hall, R., Schneider-Mayerson, M., Pope, A., Gupta, A., Rodwell, E., Ballestero, A., Durbin, T., El-Dahdah, F., Long, E., \& Mody, C. (2015). Paradoxical infrastructures: Ruins, retrofit, and risk. Science, Technology \& Human Values, 1-19.

IRENA. (2016). End-of-life management: Solar photovoltaic panels. IRENA/IEA-PVPS. Retrieved from http://www.iea-pvps.org/index.php?id=381

Jenkins, K., Mccauley, D., Heffron, R., Stephan, H., \& Rehner, R. (2016). Energy justice: A conceptual review. Energy Research \& Social Science, 11, 174-182. https://doi.org/10.1016/j. erss.2015.10.004.

Jha, M. K., Kumari, A., Jha, A. K., Kumar, V., Hait, J., \& Pandey, B. D. (2013). Recovery of lithium and cobalt from waste lithium ion batteries of mobile phone. Waste Management, 33(9), 1890-1897. https://doi.org/10.1016/j.wasman.2013.05.008.

Kishore, J., \& Monika. (2010). E-waste management: As a challenge to public health in India. Indian Journal of Community Medicine, 35(3), 382. http://www.ijcm.org.in/text.asp?2010/ $35 / 3 / 382 / 69251$.

Kumar, A. (2015). Energy access in an era of low carbon transitions: Politicising energy for development projects in India. Retrieved from http://etheses.dur.ac.uk/11387/1/Energy_Access_in_ an_Era_of_Low_Carbon_Transitions_Ankit_Kumar.pdf?DDD14+

Kumar, A. (2018). Justice and politics in energy access for education, livelihoods and health: How socio-cultural processes mediate the winners and losers. Energy Research \& Social Science, 40, 3-13. https://doi.org/10.1016/j.erss.2017.11.029.

Kumar, A., Ferdous, R., Luque, A., McEwan, C., Power, M., Turner, B., \& Bulkeley, H. (2019). Solar energy for all? Understanding the successes and shortfalls through a critical comparative assessment of Bangladesh, Brazil, India, Mozambique, Sri Lanka and South Africa. Energy Research \& Social Science, 48, 166-176. https://doi.org/10.1016/j.erss.2018.10.005.

Latour, B. (2004). Why has critique run out of steam? From matters of fact to matters of concern. Critical Inquiry, 30, 225-248.

Lepawsky, J. (2015). The changing geography of global trade in electronic discards: Time to rethink the e-waste problem. The Geographical Journal, 181(2), 147-159.

Lepawsky, J. (2018). Reassembling rubbish worlding electronic waste. Cambridge: MIT Press.

Lepawsky, J., \& McNabb, C. (2010). Mapping international flows of electronic waste. The Canadian Geographer/Le Géographe canadien, 54(2), 177-195.

Magalini, F., Sinha-Khetriwal, D., Rochat, D., Huismann, J., Munyambu, S., Oliech, J., Chidi, I. N., \& Mbera, O. (2016). Energy Africa compact-Sierra Leone final report electronic waste (e-waste) impacts and mitigation options in the off-grid renewable energy sector. Retrieved from https://assets.publishing.service.gov.uk/media/58482b3eed915d0b12000059/EoD_ Report_20160825_E-Waste_Study_Final-31.08.16.pdf

Malandrino, O., Sica, D., Testa, M., \& Supino, S. (2017). Policies and measures for sustainable management of solar panel end-of-life in Italy. Sustainability (Switzerland), 9(4), 1-15.

Millington, N., \& Lawhon, M. (2018). Geographies of waste. Progress in Human Geography. https://doi.org/10.1177/030913251879991. Retrieved from http://journals.sagepub.com/doi/10. $1177 / 0309132518799911$

Mol, A. (2002). The body multiple: Ontology in medical practice. Durham: Duke University Press.

Morris, N. J. (2011). Night walking: Darkness and sensory perception in a night-time landscape installation. Cultural Geographies, 18(3):315-342. Retrieved August 20, 2013, from http://cgj. sagepub.com/cgi/doi/10.1177/1474474011410277 
Qi, L., \& Zhang, Y. (2017). Effects of solar photovoltaic technology on the environment in China. Environmental Science and Pollution Research, 24(28), 22133-22142.

Sovacool, B. K., Burke, M., Baker, L., Kotikalapudi, C. K., \& Wlokas, H. (2017). New frontiers and conceptual frameworks for energy justice. Energy Policy, 105, 677-691. https://doi. org/10.1016/j.enpol.2017.03.005.

Sovacool, B. K., Kivimaa, P., Hielscher, S., \& Jenkins, K. (2018). Vulnerability and resistance in the United Kingdom's smart meter transition. Energy Policy, 113, 52. https://doi.org/10.1016/j. enpol.2017.07.037.

Stoler, A. (2008). Imperial debris: reflections on ruins and ruination. Cultural Anthropology, 23(2):191-219. Retrieved September 3, 2013, from http://onlinelibrary.wiley.com/doi/10.1111/ j.1548-1360.2008.00007.x/full

Stoler, A. L. (2013). Imperial debris: On ruins and ruination. Durham: Duke University Press.

Turner, B. (2016). Assemblages of solar electricity: Enacting power, time and weather at home in the United Kingdom and Sri Lanka. Retrieved from http://etheses.dur.ac.uk/11550/1/BTThesis. pdf?DDD14+

Turner, B. (2019). Diffusion on the ground: Rethinking the logic of scale and access in off-grid solar. Energy Research and Social Science, 50, 1-6.

UN ESCAP. (2014). Achieving the sustainable development goals in South Asia: Key policy priorities and implementation challenges.

Open Access This chapter is licensed under the terms of the Creative Commons Attribution 4.0 International License (http://creativecommons.org/licenses/by/4.0/), which permits use, sharing, adaptation, distribution and reproduction in any medium or format, as long as you give appropriate credit to the original author(s) and the source, provide a link to the Creative Commons license and indicate if changes were made.

The images or other third party material in this chapter are included in the chapter's Creative Commons license, unless indicated otherwise in a credit line to the material. If material is not included in the chapter's Creative Commons license and your intended use is not permitted by statutory regulation or exceeds the permitted use, you will need to obtain permission directly from the copyright holder.

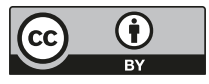

